\title{
Eleştirel Teori Açısından Hümanizm ve Mekanik: Alex Murphy Nasıl RoboCop Olur?
}

\author{
Deniz Kurty1lmaz*
}

\section{Özet}

Adorno ve Horkheimer, beraber kaleme aldıkları Aydınlanmanın Diyalektiği adlı eserlerinde modern çă̆da insan ve doğa denkleminin bir eşitlik oluşturacak şekilde kurulduğunu vurgulamaktadırlar. Üstelik söz konusu eşitliğin her iki tarafi, devamlı olarak, birbirine uyacak şekilde daralır. Araçsal rasyonalite ile doğa metalaşırken, metalaşma da insanın üretime katılan makine elemanlarına dönüşmesine sebep olur. Böylece, var oluş açısından bakıldığında, insandan geriye salt rasyonel bir zihinden ve seri üretim yapan işlevsel bir el'den başka bir şey kalmaz. İki felsefecinin bu görüşlerini, yönetmenliğini José Padilha'nın üstlendiği, serinin 4. filmi olan 2014 yapımı RoboCop filminde görmek mümkündür. Filmde, bir sibernetik organizma hâline gelen polis memuru Alex Murphy'nin insan yanından geriye yalnızca kafasının ve să̆ elinin kalmış olması düşündürücü bir ayrıntı olmaktadır. Çalışmamız, RoboCop filmini eleştirel teorinin düşünceleri bağlamında analiz etmeyi amaçlamaktadır. Modern dönemle birlikte, insanın bir işleve indirgenmek suretiyle bir çeşit makineye dönüşmesine dair felsefi tartışmalar filmin metonimik olarak okunmasıyla irdelenecektir.

Anahtar Kelimeler: Hümanizm, Mekanizm, Robocop, Eleştirel Teori.

ORCID ID : https:/ / orcid.org/0000 - 0001 - 8123 - 8034

E-mail : denizkurtyilmaz@hotmail.com

DOI: 10.31122/sinefilozofi.492143

Geliş Tarihi - Recieved: 04.12.2018

Kabul Tarihi - Accepted: 23.12.2018 


\title{
Humanism and Mechanics in Critical Theory: How Alex Murphy Becomes RoboCop?
}

\author{
Deniz Kurtyılmaz*
}

\begin{abstract}
Adorno and Horkheimer, in their book Dialectic Of Enlightenment, emphasize that the equality of man and nature has been established to form an equality in modern ages. Moreover, mentioned parity is narrowed persistently, so that both sides fit together in precision. While nature is commodificated with instrumental rationality, commodification also causes the human to turn into machine elements involved in production. Thus, from the point of view of existence, there is nothing but a rational mind and a functional hand that makes mass production are back from humankind. It is possible to see these views of two philosophers in Robocop, 4. film of the series, directed by José Padilha in 2014. In the film, it is a thought-provoking detail that only the head and right hand are left behind from police officer Alex Murphy who will transform into a cybernetic organism soon. Our work, aims to analyze the RoboCop in the context of the thoughts of critical theory. The philosophical debates about the transformation of man into a machine by a process and reduction of modern era will be examined by a methonimic film reading.
\end{abstract}

Keywords: Humanism, Mechanism, Robocop, Critical Theory.

ORCID ID : https:/ / orcid.org/0000 - 0001 - 8123 - 8034

E-mail : denizkurtyilmaz@hotmail.com

DOI: 10.31122/sinefilozofi.492143

Recieved - Geliş Tarihi: 04.12.2018

Accepted - Kabul Tarihi: 23.12.2018 


\section{Giriş}

Amerikalı bilimkurgu yazarı Isaac Asimov'un (1920-1992), ilk kez 1942 tarihli Runaround adlı hikâyesinde ortaya koyduğu ve sonrasında kaleme aldığı diğer eserlerinde de atıf yaptığı için giderek popüler hale gelen "Üç Robot Yasası" şöyledir:

"1. Bir robot, bir insana zarar veremez ve bir insanin zarar görmesine seyirci kalamaz. 2. Bir robot, ilk yasayla çelişmediği sürece bir insanın emirlerini uygulamak zorundadır. 3. Bir robot, ancak ilk iki yasayla çelişmediği sürece kendi varlğ̆ını devam ettirmek durumundadır" (Asimov, 1950: 26).

Asimov'un kuralları, insanın kendi yarattığı aygıtlar karşısında yaşayabileceği acziyete üstü kapalı biçimde değinmekteyken böyle bir şeyin vuku bulmasına dair kolektif korkumuzu da bertaraf etmeye çalışmaktadır. Ne de olsa, Çekoslovak yazar Karel Čapek' in (1890-1938) R.U.R. [1921] adlı tiyatro oyununda ilk kez gördüğümüzden beri, robotları, isyan etmeye yatkın varlıklar olarak tasavvur etmek genel bir eğilimdir ve kurallar, gelişmiş makinelerle bir arada yaşama ütopyasının aniden bir distopyaya dönüşmemesi için rasyonel biçimde kotarılmış birer emniyet mandalıdırlar ${ }^{1}$.

Burada, Robot Anatomisi [2014] kitabının yazarı Despina Kakoudaki' nin “[y]apay insanı nasıl hayal edersek edelim, bu hayal kendimiz hakkında bildiklerimiz ya da şüphelerimize karşılık gelmektedir." (2017: 228) sözünden cesaret alarak yeni bir yolculuğa çıkabiliriz. Eğer robot, insanın varoluşsal durumunun alegorik bir tasviri olarak öne çıkıyorsa, insan ve makine ilişkisinin temelde farklılık ve karşıtlık üzerine kurulan bir öykü değil, palindromik ${ }^{2}$ bir hikâye olduğu sonucuna ulaşılmaktadır. O zaman, varsayımda bulunmanın rahatlığı içinde, makine ve insanın yerlerini değiştirerek Asimov'un yasalarını tersyüz etmek üzerine kurulu bir fantezinin peşine de düşebiliriz ki o zaman ortaya şöyle bir şey çıkacaktır:

1. Bir insan, bir makineye zarar veremez ve bir makinenin zarar görmesine seyirci kalamaz. 2. Bir insan, ilk yasayla çelişmediği sürece bir makinenin emirlerini uygulamak zorundadır. 3. Bir insan, ancak ilk iki yasayla çelişmediği sürece kendi varlığını devam ettirmek durumundadır.

Şimdi dikkat çekici olan, yeni yasaların garip biçimde bize tanıdık gelmesidir ve bu aşinalık, yalnızca, makinelerin Spartacüsvari bir başkaldırıdan sonra dünyayı ele geçirdikleri zaman insanlara yapacaklarını konu alan bilim kurgu literatüründen alışık olduğumuz karanlık bir geleceği anımsatmasıyla açıklanamaz. Türettiğimiz yeni kuralların şu anki gerçekliğimize matuf bir mantığı taşıdığ1 da görülür. Fark edileceği üzere yeni kurallar üretim yapan makinelerle onları kullanmak durumunda kalan insanlar arasındaki ilişkiye dair, özellikle Sanayi Devrimi'nden bu yana kavileşen zımni kurallardır -hatta kimi zaman bu kuralların fabrikalarda yürürlükte olan benzer talimatnameler yoluyla tam anlamiyla resmiyet kazandıkları da bir gerçektir. Dahası, yeni kurallarda beliren mantık yalnızca üretim

1 Bugün, kusursuz çalışan mekanik aygıtları imleyen "robot" kelimesi, Čapek tarafından, Slavcaya uzanan etimolojik kökeniyle "robota" dan türetilmiştir ve sözcük "kölelik" ya da "ağır çalışma" gibi anlamları karşılamaktadır. Buna uygun düşecek biçimde, Çekoslovak yazarın eserinin konusu da bir fabrikada üretim yapan robotların ağır çalışma koşulları sebebiyle insan efendilerine isyan etmesinde düğümlenmektedir. Oyunun ilk kez sahnelenmesinden bu yana yaklaşık yüz yıl geçmesine ve bu süre zarfında sayısız eser verilmesine rağmen, köleliğe ya da ağır biçimde çalıştırılmaya karşı giriştikleri bir isyan hareketi sonunda, makinelerin insanlardan acımasızca öç alması temasının neredeyse her robot anlatısında değişmeden karşımıza çıkması kolektif kaygımızın derinliğini ele vermesi açısından son derece ilginçtir.

2 Palindrom, "Pay ederek iki kerede yap." örneğinde olduğu gibi, tersinden de aynı şekilde okunan ve aynı anlama gelen sözcük ya da tümcelere verilen isimdir. 
süreçleriyle sınırlı kalmaz. Teknik uygarlığımızın makineyi yaşamımızın her anında tâbi olmak zorunda olduğumuz bir üst-varlık'a dönüştürdüğü kabul edilirse, ilk bakışta son derece abartılı görünen üçüncü yasanın dahi sandığımızdan daha etkili olduğu meydana çıkar.

Esasında, teknik meselesiyle arasında belli bir mesafe olan herkes, fakat özellikle eleştirel teori mensupları ${ }^{3}$, yukarıdaki yer değiştirmenin uzunca bir süredir farkındadır. Örneğin Herbert Marcuse (1898-1979), Tek Boyutlu İnsan [1964] adlı eserinde, çağdaş insanın kendi ürettiği yapıların tahakkümü altında ezilerek yaşamaya mahkûm olduğunu anlatmaya çabalar; teknik de bu yapılardan biridir. Marcuse, "[t]eknik gelişimin belirtisi olarak, ileri endüstriyel toplumlarda, rahat, akla yakın, pürüzsüz, demokratik bir özgürsüzlük hüküm sürer." (1968: 27) diyerek insanın varoluş daralmasının evvela ve her şeyden çok teknik ilerlemeyle alakalı bir mesele olduğunu ifade etmektedir. Gelişmiş teknik uygarlığın köleleri, yüksek bir düzeye getirilmiş endüstriyel yaşam tarzına sıkı sıkıya bağlı olarak yaşayan insanlardır. Üstelik refah ya da teknolojiye ulaşma imkânlarının bolluğu açısından yüksek bir düzeyde olmak köleliğin kusursuz biçimidir: insanın üretim cihazlarına tabi kılınması; "bir araç olarak, bir şey olarak yaşamasi" ${ }^{4 \prime}$ (Marcuse, 1968: 65-66).

Bununla beraber, ilk iki yasanın nispeten baskın olduğu geleneksel paleoteknik evre ile şu an yaşadığımız ve üçüncü yasanın ağırlığını giderek daha çok hissettiğimiz çağdaş neoteknik evre arasında bir fark da vardır ${ }^{5}$. Makinelerle geleneksel ilişkimizde insan, makine tarafından devamlı yabancılaştırılır ve bu yabancılaştırma bile esasında insan olmanın önemini imlemektedir. Oysa yeni teknolojiler ve yeni makineler, insana yabancılaşabileceği bir ontolojik boşluk bile bırakmamaktadır (Crary, 2015: 62-63). Yeni tip ilişkide, insan ve makine entegre bir devre oluşturmaktadır: Artık insan-makine hâline gelinir; bu noktada insan mı yoksa makine mi olduğumuz sorusu antropolojik bir problem olmaktan çıkar ve felsefi bir muammaya dönüşür (Baudrillard, 2012: 58-59). Fakat şurası açıktır ki "makinelerimiz rahatsız edici şekilde hayat doluyken bizim korkutucu ölçüde atıl olmamı" (Harraway, 2010: 50), tıpkı türettiğimiz üçüncü yasanın öngördüğü gibi, varlığımızın ancak makinenin bünyesine katılması oranında değer bulabildiğini anlamına gelmektedir.

Kaldı ki, teknik gereklilikler tarafından yönlendirilen sistemimiz, varlığını insani ihtiyaçları tatmin ederek sürdürmez, tam tersine, insan davranışları makinenin ihtiyaçlarına

3 Eleştirel teori sözcüğü 1923 yılında kurulan Frankfurt Toplumsal Araştırma Enstitüsü'nün Adorno, Horkheimer, Marcuse ve Benjamin gibi üyelerinin ve haleflerinin fikirlerini karşılamak için kullanılırsa $\mathrm{da}$, çalışmamızda bu isimlerle sınırlı kalınmamıştır. Eleştirel teoriye mensubiyetin soyut ve olabildiğince geniş bir çerçevede ele alındığı bildirimizde, kaygılarının ortaklığından hareketle, kapitalizmendüstriyalizm-mekanizm-hümanizm bağıntısına karşı sorgulayıcı bir tavır takınan her düşünür bu kurgusal çerçeveye dâhil edilmiştir. (Frankfurt Okulu ve görüşleri ile ilgili temel bir inceleme için bkz. Raymond Guess, Frankfurt Okulu, İstanbul: Ayrıntı Yayınları; daha geniş bir çalışma içinse bkz. Phil Slater, Frankfurt Okulu, İstanbul: Kabalcı Yayınları.)

4 Vurgular tarafımızdan eklenmiştir.

5 Paleoteknik ve neoteknik kavramlarını Amerikalı tarihçi ve bilim felsefecisi Lewis Mumford'a (18951990) borçluyuz. Mumford, ilk kez 1934 yılında yayınlanan Teknik ve Uygarlı adlı yapıtında tekniğin üç dönemli bir gelişim geçirdiğini vurgulamaktadır. Tedrici dönüşümleri içerdiği için dönemleri birbirinden kesin tarihlerle ayırmak mümkün olmasa da, Mumford'un "güç ve karakteristik materyallerle ilişkili olarak ele alındığında, eoteknik evre bir su ve tahta bütünü, paleoteknik evre bir kömür ve demir bütünü, neoteknik evre de bir elektrik ve alaşım bütünüdür" (2017: 114) ifadesi kabaca bir dönemlendirme yapmayı mümkün kılar. Buna göre, eoteknik dönem ilk aletlerin yapımından yaklaşık olarak 17. yüzyılın ikinci yarısına kadar sürmüş ve yerini 19. yüzyılın ortalarına kadar devam edecek olan paleoteknik döneme bırakmıştır. O tarihten itibarense neoteknik dönemin hükmünü icra ettiği söylenebilir. 
uyacak şekilde değiştirilmektedir (Kacznsky, 2013:54). İnsan, makinenin öğütücü mantığından yine makineyle birleşmek suretiyle kurtulmaya çabaladıkça siborglaşmaktadır. Bu, klasik manada insanın ölümü olsa bile gidilecek başka bir yol yoktur; makineye zarar vermeden ve onun emirlerine uyarak varlığımızı sürdürebilmenin tek yolu budur (Batukan, 2017: 31). Böylece bir kez daha yapay insanlara dair temsillerin özünde insana dair tahayyüller olduğu savına ulaşılmakta; edebiyat yahut sinemadaki robot temsillerinin, insanın seri üretime katılmak durumunda olan bir "araç" ya da yine seri üretimin sonucu olarak vücut bulan bir "şey" olmasının hikâyesi olarak irdelenmesinin yolu açılmaktadır. Farkında olsun ya da olmasın, uzunca bir zamandır insan kendine baktığında bir robotu, bir robota baktığında ise kendini temaşa etmektedir.

Vardığımız yere çıkan yolun başlangıcını ise modern dönemin doğuşuna; hümanizmin yalnızca sanatta bir eğilimolmaktançıkarak kuramsal bir kimliğe sahip olduğu Kartezyen dünya tasarımına dayandırmak mümkündür. Söz konusu tasarım, insan aklına ayrıcalıklı bir konum vermiş, aklın karşısında konumlandırdığı doğayı da matematik yasaların kesinliğinde çalışan zihin tarafından anlaşılmaya uygun salt mekanik ilişkiler bütünü olarak değerlendirmiştir. Böylece zihin ve dünya arasında belli oranda eşitlik kurulabilecek bir denklem oluşturulmuşsa $\mathrm{da}, \mathrm{bu}$, aynı zamanda insanın da mekanik bir tasarıma dönüşmesinin; kesinlik üreten zihnin kendisinin de ürettiği kesinliğe tâbi olması zorunluluğunun ilk adımıdır. İlaveten, insanlık tarihi açısından son derece büyük olan Kartezyen sıçramanın, eoteknik evreden paleoteknik evreye geçişi mümkün kıldığı gibi, akılcılaştırmanın standartlaşma fikri ile el ele vererek ilerleme ülküsüyle birleşmesi neticesinde Sanayi Devrimi'ne ve en nihayetinde endüstriyel kapitalizme de vücut verdiği ortadadır. Teorik ve pratik uygulamaların bütünlüğü içinde ortaya çıan çağdaş sistem, "bugün tüm yerküreyi içine alacak biçimde genişlemiş olduğundan" (Wallerstein, 2012: 99) kaçılabilecek bir yer de bulunmamaktadır.

Bu çalışma, yukarıda değinilen kavramsal çerçeveden hareketle 2014 yapımı RoboCop filmini felsefi açıdan irdelerken makinenin insanlaşmasını değil de, insanın makineleşmesini mercek altına almaktadır. Hümanizmin, 17. yüzyılda felsefi bir temele oturarak günümüze kadar süren tarihi yolculuğunu ancak mekanizmle birlikte yapabileceği, fakat kapitalizmin sırtını yasladığı endüstriyel üretim ve tüketim ilişkileri bağlamında her ikisinin de başta hayal edilenden çok daha farklı bir noktaya taşındığı fikri temel alınmıştır. Burada dikkati çekmesi istenen husus, hümanizm, mekanizm, endüstriyalizm ve kapitalizmin, bir düzen içinde ve birbirlerini besleyerek insana yeni bir var olma biçimi dayattı̆̆ıdır. Diğer bir ifadeyle, çalışmamız açısından modernlik, her şeyden çok, söz konusu bağıntı içinde şekillenen yeni bir insan-oluş biçimidir. Robot anlatılarının irdelenmesi ise yeni insanlık durumumuzu daha iyi kavramak konusunda bize yardımcı olabilir. Bu fikirleri eleştirel bir perspektiften ele almak gayretinde olan çalışma, filmi betimsel analiz yöntemiyle incelemeye tabi tutmaktadır. Bu yönteme uygun olacak şekilde, filme ait sahneler, diyaloglar ya da bazı görsel unsurlar metonimik olarak yorumlanmış; parça-bütün ilişkisi bağlamında ve çizilen kuramsal çerçeve özelinde tahlil edilmiştir.

\section{Robotların Manevi Babası Descartes}

Brezilya asıllı yönetmen José Padilha tarafından çekilen RoboCop, 1987 senesinde başlayan bir serinin dördüncü filmi olarak 2014 yılında seyirciyle buluşmuştur ve konusu 
büyük ölçüde ilk filmin yeniden işlenmesinden ibarettir ${ }^{6} .2028$ y1lında, Detroit merkezli bir firma olan Omnicorp sibernetik teknolojileri alanında çalışmakta ve Amerikan ordusunun deniz aşırı görevlerinde kullanılmak üzere asker-robotlar üretmekteyken yürürlükteki bir yasa gereği robotlarını Amerikan pazarına sokamamaktadır. Diğer yandan, Detroit Polis Teşkilatı'nın gözü pek dedektifi, eşine ve oğluna karşı son derece müşfik bir aile reisi olan Alex Murphy (Joel Kinnaman), peşinde olduğu bir suçlu tarafından otomobiline yerleştirilen bombanın infilak etmesi sonucu ağır şekilde yaralanır. Omnicorp, durumu kritik olan Memur Murphy'in hayatını kurtarmak adına onu sibernetik bir organizmaya çevirerek RoboCop'a dönüştürür, aynı zamanda bu yolla iç güvenlikte robotların kullanılmasını yasaklayan Dreyfus Yasası'nı legal bir biçimde alt etme şansını da yakalar. Artık büyük ölçüde bir makine olan Alex Murphy bir yandan yeni haline adapte olmak konusunda yaşadığ 1 varoluşsal sıkıntılarla ve ona karşı dürüst olmayan Omnicorp şirketiyle baş etmeye çalışırken bir yandan da ucu kirli polislere dek uzanan bir suç şebekesinin peşine düşecektir.

Bizim için hikâye, asker-robotları üreten Omnicorp şirketinin CEO'su Raymond Sellar (Michael Keaton) ile makineleri Amerika'dan uzak tutmaya çalışan Senatör Dreyfus (Zach Grenier) arasındaki ilginç konuşmayla başlamaktadır. Makinelere, insan olmanın anlamını kavramayacağı için güvenmeyen ve "Ölüm kalım konusunda doğruyu yanlıştan ayıran insanlara ihtiyacımız var." diyen Senatör, Sellar'a "Makineleriniz ne hissediyor?" diye sorar. Sellar ise makinelerin ne hissetmediklerini söylemeyi yeğler: "Sinirlenmiyorlar, önyargılı değiller, yorulmuyorlar..." Makineler insanın kusurlarını taşımamaktadır; çünkü bir şey hissetmemektedirler. Senatöre göreyse bu, robotları Amerika'dan uzak tutmak için başlı başına yeterli bir sebeptir. Bir şey hissetmemek aynı zamanda ahlaki sorumluluk alamamak olduğundan, insan hayatının değeri konusunda empati geliştiremeyecek makinelere insanların güvenliğini emanet kabul edilebilir bir şey değildir.

Oysa tipik bir kapitalist portresi çizen CEO için ahlaki sorumluluklar umursanacak son şeydir; o yalnızca yürürlükteki yasa nedeniyle robotlarını Amerikan piyasasına sokamamaktan dolayı kaybettiği paranın derdindedir. "Amerikalılar bir makine değil, bilinci olan bir ürün istiyorlar." diyen Sellar sonunda Dreyfus'un ve yasayı destekleyen Amerikan halkının gözünü boyayabilecek bir çözüm bulur: "Makinenin içine bir insan yerleştireceğiz." Omnicorp'a aradığı bu fırsatı ağır yaralandıktan sonra bedeninde başı ve sağ elinden başka sağlam yeri kalmayan Alex Murphy verecektir. Şirket, Murphy'nin sağlam kalan yerlerini tamamen makineden oluşan bir bedenle birleştirecek ve böylece RoboCop doğacaktır.

6 Sinema filmlerinin ilki 1987, ikincisi 1990 ve üçüncüsü 1993'te çekilen RoboCop, 1994 ve 2001 yıllarında iki kez televizyona dizi olarak uyarlanmıştır. Ayrıca RoboCop'un, 1988 ve 1998 yıllarındaysa iki kez çizgi film serisi yapıldığı gibi, 1987 senesinden bu yana Marvel tarafından yayınlanmaya devam eden çizgi romanı da bulunmaktadır. Polisiye-aksiyon türüne yaklaşan çizgisinin ötesinde, serinin her filmi kendi zamanının sosyo-ekonomik ilişkilerini yansıtan bir ayna vazifesi de görür. Bu türden bir analiz ve 1987 ile 2014 yapımı filmler arasında bir karşılaştırma için bkz. Milo Sweedler, "Class warfare in the RoboCop films", Jump Cut: A Review of Contemporary Media, No. 56, winter 2014-2015.

7 Filmin hemen başındaki post-kolonyal klişelerle yüklü sahneler (Amerikan ordusunca işgal edilmiş İran, Tahran sokaklarında devriye gezen asker-robotlara saldıran intihar bombacıları, askerler için bir tehdit oluşturmasalar bile gayet sevimsiz biçimde gösterilen yerli halk vs.) ya da çağdaş medyanın her şeyi sansasyonel bir olay hâline getirmesi gibi hususlar başka çalışmaların konuları olarak ayrıca irdelenmeyi hak etmektedirler. 


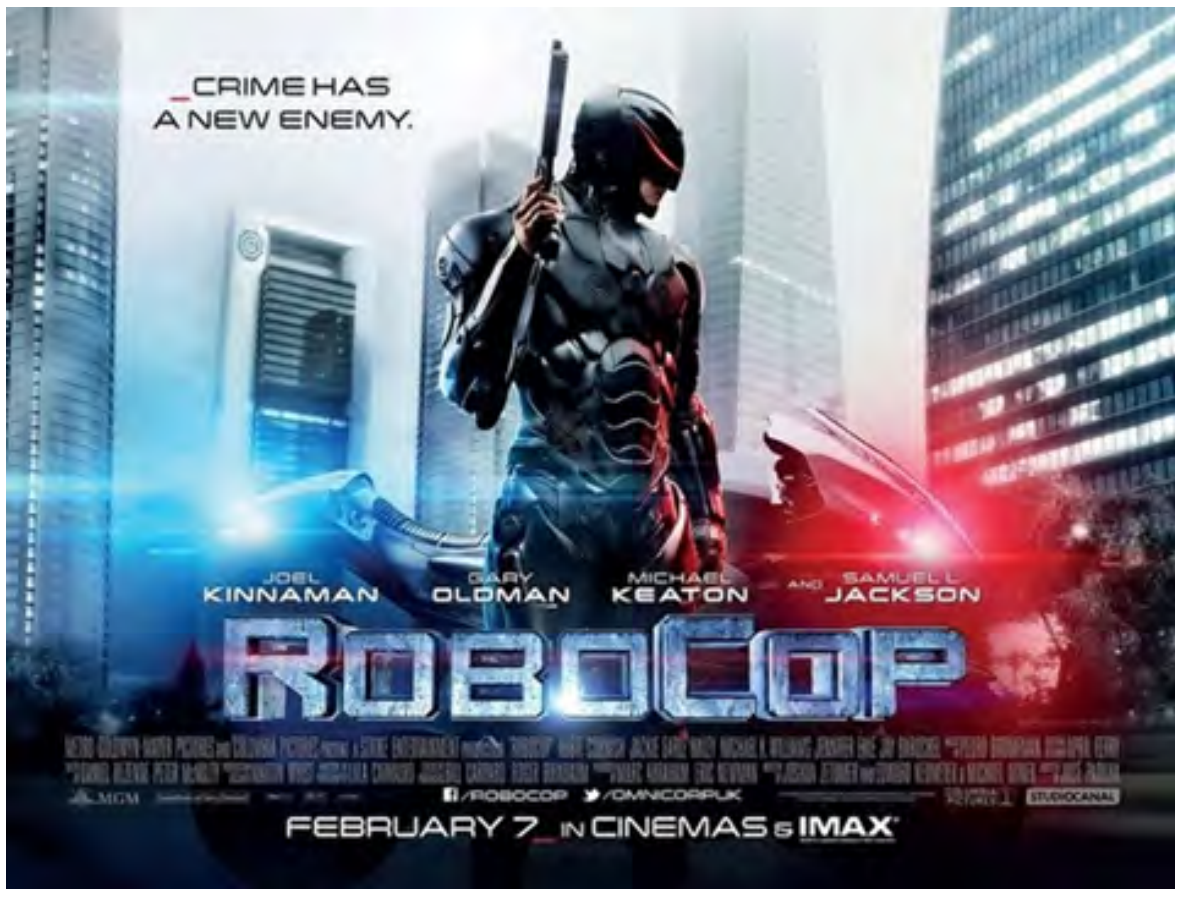

Görsel 1. RoboCop Filminin Afişi

Herhangi bir robot anlatısı söz konusu olduğunda, anlatının felsefi derinliği ilk elde Kartezyen tasarıma çok şey borçludur (Kakoudaki, 2017: 226) ve RoboCop filminde de bu borç asla birbirinden tam anlamıla yalıtılamayacak iki kalemde birikir. İlk kalem, zihin ve beden düalizmidir. Zihin ve bedenin birbirinden ayrılması, her şeyden önce bir robotun kendisinde açık biçimde görülür: Robot anlatılarında zihin, benliği meydana getiren ana töz iken, beden sökülüp takılabilen parçalardan müteşekkil bir makine-organlar toplamıdır. İkinci kalem ise mekanikçi dünya tasarımının oluşmasıdır. Descartes, her ikisiyle ilgili çıkarımlar yaptıkça, gelecek çağların insana ve dünyaya bakışını ele veren sembol isim olarak öne çıkar ${ }^{8}$ ve düşünceleri de hâlâ etkisini sürdürmektedir. Öncelikle, Fransız düşünürün mekanikçi tutumu, tüm tabiatın, uzam içinde devinen maddeler toplamından müteşekkil bir makinaya benzetilmesiyle sonuçlanır. Onun için insan bedeni de, "bir cesette bile görebileceğimiz türde organlardan ibaret bir makinedir" (2013: 41). Buna karşın, insanda hareket yasalarına değil fakat apaçık matematik kesinliğe tâbi, "açık ve seçik olarak kavradığı şeyler üzerine yargıda bulunduğu takdirde hiçbir zaman aldanmayacak" bir zihin bulunmaktadır (Descartes, 2010: 76). Söz konusu ayrım, modern düşüncenin çekirdeğini oluşturan hümanizmin felsefi temeli olarak da önemlidir zira "hakikatin bilinmesinde referans noktası olarak insan aklının merkeze alınması" (Küçükalp ve Cevizci, 2017: 153) demek olan hümanizmin, evvela, duyuları yoluyla

8 Elbette, mekanikçi felsefenin yalnızca Descartes'a ait olduğunu iddia etmek doğru değildir. Rönesans'ın natüralizmine karşı olarak gelişen mekanik dünya anlayışını, 17. yüzyılın ilk yarısı boyunca Galileo, Kepler, Toricelli, Boyle, Gassendi ve Hobbes gibi isimlerin teorik ve pratik alandaki çalışmalarında da görmek mümkündür. "Yine de mekanikçi bir doğa felsefesinin oluşmasındaki gerçek etkinin sahibi René Descartes'tır (1596-1650). Descartes bütün aşırılıklarına karşın, mekanikçi anlayışa -şiddetle gereksinme duyduğu- felsefi bir kesinlik kazandırmıştır" (Westfall, 2008: 35). Diğer yandan, 17. yüzyıl mekanizminin ardında Rönesans kültürü içinde gelişen makineler tasarlama itkisinin bulunduğu da gözden kaçmamalıdır (Sawday, 2007). Sınırlılıklar gereği tüm tarihi süreci ele almak mümkün olmadığından, çalışmamızda Descartes, bir nevi soyutlamaya tabi tutularak kendinden önceki geleneği damitıp saflaştıran bir kurucu figür olarak öne çıkarılmıştır.

9 "Makine tarafından doğa güçlerine bağlı olmaktan kurtarılan ve insanlığa boyun eğdiren kötülüklere karşı zafer kazanmış bir insanlığa dair Kartezyen hayal Avrupa'yı iki yüzyıldan fazla bir süre boyunca hareketlendirmiştir. Bugün bile halen bu hayal canlı ve etkindir" (Koyré, 2013: 133-134). 
yanılgıya düşebilecek bir bedene karşın, hakikati tümüyle kavramaya muktedir şaşmaz bir zihne ihtiyaç duyduğu açıktır.

Filmde Omnicorp'un sibernetik bölümünün başında bulunan Dr. Dennet Norton (Gary Oldman) son derece gelişmiş protez ellerine yeni kavuşmuş olan bir hastasını gitar çalmak için cesaretlendirirken modern çağın insan tasavvurundaki Kartezyen ayrımdan beslenmektedir: "Sen, bacakların, kolun, ellerin yüzünden sen değilsin. Sen, beynin yüzünden sensin. Seni sen yapan bilgiyi işleyen beyninin kapasitesi". Doktorun bu sözlerinden kuvvet alarak yeni mekanik elleriyle gitarını -belli ki uzun bir aradan sonra- ustalıkla çalmaya başlayan hasta, zihin-beden ayrımı hususunda beyin ve sinir merkezli bir insan tasavvurunu savunan Dr. Norton'u haklı çıkarırken Descartes'a da selam göndermektedir. Aynı şekilde, RoboCop haline gelen Alex Murphy, bir aynanın karşısında ${ }^{10}$ kendisinden geriye kalanın sadece bir kafa ve bir sağ el olduğunu görüp dayanılmaz bir acı duyduğunda da Dr. Norton benzer sözler sarf edecektir. Memur Murphy "Yüce Tanrım! Yüce Tanrım, geriye hiçbir şey kalmamış!" diye feryat ettiğinde, Doktor, "Vücudun gitmiş olabilir ama sen hâlâ buradasın." diyecek ve bu sözlerden sonra Alex'in şeffaf bir kafatası içine oturtulmuş beyninin gösterildiği bir plana kesme yapılacaktır.

Zihin-beden düalizmi ilk bakışta ikna edici ve masum görünebilir fakat eleştirel düşünürler açışından söz konusu ikiliğin arkasında yatan mantık öngörülemeyen ciddi problemler üretir. Mekanik dünya resmindeki ilk ve en büyük hata insan organizmasının parçalanması; aklın, vücudun geri kalanı olmaksızın çalışabilecek bir merkez olarak telakki edilmesidir. Mekanik dünya tasavvuru altında hümanizmin, insan sayılana dair kısıtlı bir fikre sahip olduğu için (Braidotti, 2018: 28), esas olarak, insana gerçekten bir yer verip vermediği bile şüphelidir. Verse bile, insan zihni bir daralma yaşayarak "düşünüyorum"a indirgenir. Bedenin işlevden ibaret kalan işleyişini zihin de rasyonel düşünceye mahkûm olarak devam ettirmek zorundadır (Adorno ve Horkheimer, 2010: 47). Zira “fiziksel dünyayı ve nihai olarak bu dünyada var olan insanın kendisini, sadece kütle ve hareketin bir ürünü olarak algilamak için kişi, canlı ruhunu bertaraf etmelidir" (Mumford, 1996: 94-95). Modernliğin ethos'unu dünyadaki animizmin yok edilmesi olarak gören Adorno ve Horkheimer için de durum tam olarak böyleyken (2010: 19-21), Kakoudaki için durum bundan biraz daha karmaşıktır. Kartezyen tasarımın koşulladığı düalizmin sonucu çarpık bir animizmin geri dönmesidir. Descartes'in bedenden tamamen ayrılmış tinsel ruhu, bedenin devingenliği ve yaşamıyla hiç bağlantı kuramadığı; biçim ve özün bir arada olamadığı bir kavramlaştırmada canlılığın kaynağı olarak kabul edilse bile, öz'den ziyade bir hayalet muamelesi görecektir. Bedenle ruh arasındaki bağ, kendilerine özgü bir zorunluluktan kaynaklanmadığı için ruhun kendine ait bir amacı olup olmadığından emin olmak mümkün olmaz (Kakoudaki, 2017: 131).

10 Ayna, robot anlatılarında çok sık gördüğümüz bir unsur olarak, kahramanın yaşadığı kimlik bunalımını aktarmak için kullanılır (Smelik, 2010: 93). Alex Murphy de yeni varoluşuna dair korkunç bir bunalımı yaşarken yine bir aynanın karşısında kendisine bakmaktadır. 


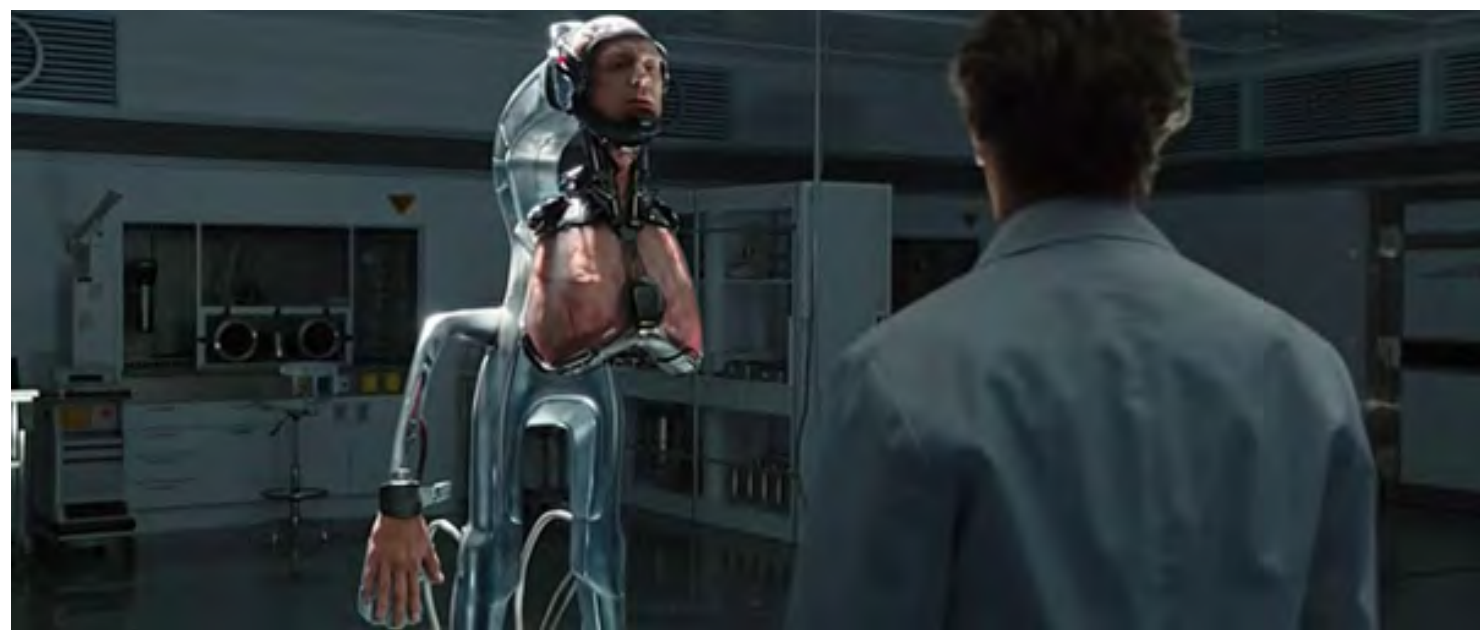

Görsel 2. Alex Murphy'den Geriye Kalanlar: Bir Beyin, Bir Sağ El

Bu sebepledir ki, robot anlatılarının modern canlandırma sahneleri başarısız olmuş törenleri bize sıkça göstermektedir. Bu yeni varlık, olması gereken duruma bir türlü geçemez; durağan ve hareketsiz olma eğilimi gösterir. Fakat durağan ve hareketsiz olması gereken yerde de aşırı bir hareket görülebilir (Kakoudaki, 2017: 69). Zira zihne indirgenmiş ruh, makineden ibaret kalan bedenin işleyişine sürekli müdahale ederek problem çıaran bir bela haline gelmiştir.

Büyük kısmı dijitalleştirilmiş ve böylece işlev açısından kusursuzlaştırılmış zihnine Detroit Polis Teşkilatı'nın veri tabanı yüklendiğinde, işlenen bütün suçlara bir anda tanık olmak RoboCop'u zihinsel açıdan dengesizleştirir. Dr. Norton' un asistanı durumu "duyguları ağır basmaya başladı" diye özetlerken, kendi cinayet dosyasına eriştiğinde RoboCop tamamen kontrolden çıkar ki teknisyenlere göre bu "bir bilgisayar hatasıdır" ve düzeltilmesi gerekmektedir. Başka bir deyişle, hisseden ve ahlaki bir acıyı yaşayan bir insan, bir an önce, işlediği bilgiler ne olursa olsun kayıtsız kalacak ve "bunlardan bir mana çıkarmayacak bir makineye" (Postman, 2006: 131) dönüştürülmelidir. Asistanı "hissetme yeteneğini elinden alacaksınız" diye uyarmasına rağmen Dr. Norton çareyi RoboCop'un dopamin ve noradrenalin hormonlarını sisteminden tahliye ederek onu herhangi bir duygu hissedemeyecek bir bilinç durumuna getirmekte bulur ${ }^{11}$. İşlem işe yaramıştır; Alex nasıl hissettiği sorusuna bir makine soğukluğuyla cevap verir: "İyi hissediyorum Dr. Norton.” Aslında bu söz zekice kurgulanmış bir aldatmacadır: Alex Murphy artık hiçbir şey hissedemeyen bir makinedir, fakat bir makinenin bir şey hissetmemesi başlı başına iyi bir şeydir.

Böylece, filmin başında tanık olduğumuz, Senatör Dreyfus'la Sellar arasındaki diyalog gerçeğe dökülür. Alex Murphy, kapitalist Sellar'ın ürettiği makinelerden biri olmuş; bir şey hissetmez hâle gelmiştir. Sahnenin devamında uzunca bir süredir kanundan kaçan bir suçluyu herkesin önünde gözünü kırpmadan vurması Senatör'ün korkularını haklı çıarsa da, RoboCop, medya ve toplum tarafından, işlevini kusursuzca yerine getiren bir aygit olarak alkışlanacaktır.

Uzunca bir süre duygularından arınmış olarak işlevini mükemmelen yerine getirse de bir zaman sonra makinede bir aksaklık kendisini gösterecek; Alex, eşi ve çocuğuyla yüzleşip

11 Bu sahne, hissetmenin bile biyolojik süreçlere indirgenmesini göstermesi açısından da anlamlıdır. Düşünmek ya da hissetmeye dair yorumların mekaniğe değil de biyolojik süreçlere atıf yapmaları özü değiştirmez; bu türden çıkarımlar modern çağın indirgemeci ideallerinin çatısı altında birleşirler. 
hislerini kendiliğinden geri kazanınca bu durum tüm bilim insanlarını şaşırtacaktır. "Yapı ve fiziğin ötesinde bir şeyin sisteme müdahale ettiğinden" bahseden doktorlara Omnicorp yöneticilerinden biri "Ne mesela? Ruhu mu?" diye soracaktır. Sorudaki alaycı ton gözden kaçmayacak kadar belirgindir çünkü sadece düşünüp işlem yapan mekanik bir aygitta ruh, var olmasını kabul edemeyeceğimiz bir hayalettir.

\section{Prometheusçu Utancımız ve Makine Standartları}

Diğer yandan, 16. yüzyılla birlikte artık iyice seçilmeye başlayan "canlı olan ile mekanik olanın birbirinden ayrılması" (Mumford, 2017: 41) aynı zamanda düzenli ile düzensiz olanın ayrıştırılması demek olduğundan, insanın hakiki varlığının kusursuz işleyen ve bedene nispetle ölümsüz olan bir zihne indirgenmesi tek başına yeterli değildir. Zira res cogitans ve res extensa ayrımına giden ${ }^{12}$ ve bu ayrı varlık alanlarının yasalarında bir denklik olması gerektiğine inanan mekanikçi dünya görüşü için dış dünyanın da rasyonel yasalara göre düzen içinde işleyen bir yapı olarak tasavvur edilmesi zaruridir. Rasyonelliğin doğanın kendisine içkin bir nosyon olduğu; doğanın, tek tek parçaların kusursuz uyumuyla şekillenen bir bütünü meydana getirdiği fikri dünya tasarımının büsbütün değişmesi; “düzenin Tanrı' dan makineye aktarılmasıdır" (Mumford, 2017: 44). Bundan böyle ihtiyaç duyduğumuz düzen ve akılcılığın garantörü Tanrı değil, mekaniktir; makinedir.

Descartes'ın hesap ettiğini zannetmediğimiz ${ }^{13}$ bir yer değiştirme gerçekleşmektedir. Varlığı ve gerçekliği (doğruluğu) kesin olarak kanıtlanmış zihinle görece düşük değerdeki dış dünya, mekaniğin yasaları altında kavramsal statülerini değiş tokuş ederler zira insan kişiliğinin yalnızca bir tarafını teşkil eden akılcılık ve düzen, makine yoluyla tabiatın tamamina somut biçimde uygulanabilir (Freyer, 2014: 37-38). Bu noktada Jean Baudrillard (1929-2007) hümanizm ve mekanizm arasındaki ilişkinin yakınlık ve geçişkenliğine, tekniğin dünyasına insani bir amaç kazandırma düşüncesinin insanların hayatına teknik bir işlevsellik kazandırmak anlamına geldiğini söyleyerek dikkat çekmektedir. İnsan, makine fikrinden yola çıarak ürettiği hayaller eliyle her şeye, fakat özellikle de kendine, işlevsellik kazandırma fantazyasına kapıldığını idrak edemez. Burada bize göz kırpan yine Kartezyen düşüncedir: “İnsanların dünyaya müthiş bir işlevsellik yükledikleri masalın kökeninde, insan bedenine yüklenen o müthiş işlevsellik masalı vardır" (2014: 146-17).

Fakat bu, insanın önüne kesinlikle insan-dışı bir mükemmellik standardının konması demektir (Mumford, 2017: 297, 326). İnsan-dışı standartların dayatılmasını genişçe irdeleyen Polonya asıllı felsefeci Günther Anders (1902-1992) ise mekanik hayranlığımıza bir utanç duygusunun eşlik ettiğini iddia etmektedir. Anders'e göre modern insan, makinelerin kusursuz düzeni karşısında onlar kadar kusursuz olamamanın yarattığı aşağılık kompleksi ile "Prometheusçu utanç" içinde yaşamaktadır. Hatta hümanizmin kendi kendini var eden insan imgesinin altında bile söz konusu utanç gizlenmektedir. İnsanın kendini imal etmek istemesi, Tanrı ya da doğa tarafından yaratılmış bir şey olmaktan kurtulma arzusundan çok, imal edilmemiş bir şey olmaktan kurtulmaya çalışmasıyla ilgilidir. İmal edilmiş şeylerdeki düzen modern insanı büyülediğinden Prometheusçu utancı bastırmak için aygıtların safına

12 Descartes'in düşüncesinde res cogitans düşünen zihin, res extensa ise yer kaplayan maddedir ve iki ayrı tözü meydana getirirler (Descartes, 2010: 82).

13 Makine Efsanesi [1967-1970] adlı yapıtında Lewis Mumford şöyle demektedir: "Mekanik dünya resmini yaratanlar birçok aktüel icat ve keşifleri önceden gördüler ve bunları meydana getirmek için oldukça hırslıydılar; fakat zihinlerinde dahi, kendi çabalarının korku verici toplumsal sonuçlarını tahmin edemediler" (1996: 114). 
geçmek de kaçınılmaz olmaktadır: İnsan artık, "aletlerin aleti olarak" insandır. O, bundan böyle, "yapılmış bulunan mekanizmalar dâhilinde ya da belirlenmiş teknik tasarımlar dâhilinde işlenmiş bir parça olarak insan" dır (Anders, 2018: 38, 48-49). İnsanın mekanizmalar dâhilinde bir parça olmak adına kaybetmek durumunda kaldığı şeyleriyse Lewis Mumford Makine Efsanesi adlı yapıtında şöyle özetlemektedir:

Insan ancak, organik komplekslikten kurtulma, onu tecrit ve zihinsel sterilizasyon yoluyla saflaştırma, iç organlarımı boşaltma ve geri kalanı ideolojik mumya bezleriyle sarmalama vasıtasıyla kendisine ait mekanik eserler kadar kusursuz ve tam olabilirdi. Organik, özerk ve öznelden kurtulabilmek için insan bir makineye dönüşmeliydi. Yahut hiç olmazsa, yeni metodun yaratımda yardımcı olacağı büyük bir makinenin bütünleyici bir parçası olmalıydı (1996: 101).

Gerçekten de RoboCop olma yolunda Alex Murphy'nin başına gelenler, neredeyse, Mumford'un söylediklerinin birebir görselleştirilmesinden ibarettir. Makinenin yeni bir standart olarak belirlenmesi ve yüceltilmesi fikri yoğun olarak işlenmekte, hatta Mumford'un altını çizdiği gibi "iç organları boşaltılmış" bir varlığa dönüşmesine rağmen içinde hâlâ bir "insan" bulunduğu için yeterince makine olamayan Alex, açık biçimde aşağılanmaya bile maruz kalmaktadır. Omnicorp'un savaş robotları biriminin başında bulunan ve RoboCop'u ilk gördüğü andan beri ondan nefret etmişe benzeyen Rick Mattox (Jackie Earle Haley) "Makinelerimiz harika bir şekilde çalışıyor. Bana sorarsan, sistemin içine bir organizma sokmak bizim için devasa bir gerilemedir." diyerek makine üstünlüğünü vurgulamaktadır. Dahası, bir polis olan Dedektif Murphy çatışma simülasyonlarında kanl1-canlı polislerle değil tamamıyla makine olan savaş robotlarıyla karşılaştırılacak ve performansı da Mattox tarafından "kalite kontrolü" adı altında değerlendirilecektir ${ }^{14}$. Görünen o ki "insan her şeyin ölçüsüdür" sözü, yerini "makine her şeyin ölçüsüdür"e bırakmıştır"15.

Bekleneceği üzere, insani duyguları RoboCop'u yavaşlatmaktadır; çatışma simülasyonu boyunca Alex tetiği bir makine gibi soğukkanlılıkla çekemez ve robot rakibinin gerisine düşer. Oysa Omnicorp'un başındaki isim Sellar için bu kabul edilebilir bir durum değildir. Onun için bir insan anca "iyi sayılır". "İyi sayılır yetmez. Böyle bir şeyi nasıl satarım bilmiyorum, tamam mı?" diye söylenen CEO, Dr. Norton'a, Alex'i biraz daha makineleştirmesi hususunda baskı yapmaktadır. Sellar ve Dr. Norton arasındaki diyalog aygıt ve insan doğası arasındaki kapanmaz boşluğa işaret etmektedir. Bir aygıtın doğasında tek ve özel bir işi mükemmelen yapma saklıyken aygıtın bu durumu insan mühendisliğinin de omurgasını teşkil etmektedir; buna göre yeni insan, onu üretenlerce öngörülen özel edimi dışında bir işleve sahip olmamalıdır. Beklenen performans, bedensel açıdan ne kadar insanüstü olursa olsun, ortaya çıan varlık yalnızca bir fonksiyona indirgenmek istendiği için her zaman "insanaltı" bir şey olarak kalacaktır. "Burada gerçek insanın payına (elenemiyorsa eğer) sineye çekilen bir apandis olmak düşer" (Anders, 2018: 60-61).

14 Çatışma simülasyonu başlamadan önce Mattox, çalışırken müzik dinlemekten hoşlandığını belirterek manidar bir parça çalmaktadır: 1939 tarihli Oz Büyücüsü (The Wizard Of Oz / Victor Fleming, Mervyn LeRoy, King Vidor, George Cukor, Norman Taurog) filminde hissedebilen bir insan olmaya özlem duyan Teneke Adam'in söylediği "If I Only Had A Heart (Ĕger Bir Kalbim Olsaydı)". Her şeyiyle Alex Murphy'nin yeni durumuna gönderme yapan şarkının sözleri durumu özetlemektedir: "Bir insan boş bir tenekeyse eğer gayret etmeli / Ama gel gör ki ben parça parçayım / Ben de bir insan olabilirdim sanıyorum, eğer bir kalbim olsayd1..."

15 M.Ö. 481 ile 411 yılları arasında yaşamış Yunan düşünür Protagoras'a ait olan “İnsan her şeyin ölçüsüdür." sözü, sofistlerin, her bir fert özelinde sübjektif olarak şekillenen bir hakikat anlayışına vurgu yapmak suretiyle modern düşüncenin objektivizminden ayrılsa da, insanı merkeze koyması bakımından hümanistik bir muhtevaya sahiptir. Bu anlamda, yukarıdaki yargımız, sofistlerle modernler arasındaki devamlılığı epistemolojik değil ontolojik öncelikler üzerinden kurmaya dönüktür. 
Yine de Sellar, Alex'in makineye benzemesinde son derece israrcı olur çünkü Omnicorp'un hayatta kalması satılabilir bir ürünün yaratılmasına bağlıdır ${ }^{16}$. Sellar, doktora sert bir dille “Çin'e geri dön ve onu düzelt. Nasıl yaptığın umurumda değil, sadece düzelt!" diyerek görüşmeyi bitirir. Norton ve Sellar'ın sahnesi modern bilimle kapitalizmin en büyük tarihi uzlaşısını seyirciye aktarmaktadır: "İrrasyonel müdahalenin dışlandığı otomatik bir kesinlikler evreni" (Mollaer, 2016: 25).

İşinin başına dönen Dr. Norton, “Onu düzelteceğim, farkı hissetmeyecek bile.” diyerek Alex'in beynine müdahale eder. Entegre ettiği yeni bir çip sayesinde çatışma modu tamamen makinenin kontrolünde olacaksa da Alex bunu bilmeyecek, çipin ürettiği bilgiyi işlemek zorunda kalan beyni tetiği çekenin kendisi olduğunu düşünecektir. "Düşünce, her türlü hayvani ve metafizik refleksten arıtılmış beyin-omursal bir devrenin kendi yerini alması tehlikesiyle karşı karşıya olsa da" (Baudrillard, 2012: 61) benlik duygusu parçalanmaz zira “otomatikleşme ve kişiselleşme kesinlikle karşıt süreçler değildirler", yeter ki kişiselleşenin insandan ziyade makine olduğunun farkına varılmasın (Baudrillard, 2014: 141).

Yapılan cerrahi müdahale işe yarar ve RoboCop çatışma simülasyonunu kusursuz bir performansla tamamlar. Özgür irade yanılsamasının da ortaya çıkışıyla birlikte mekanik dünya tasavvurun en başından beri bir potansiyel olarak taşıdığı itki bütünüyle gün yüzüne çıkar; makinenin insan üzerindeki hâkimiyeti sınırsız olur. “[i்]nsan şahsiyetini küçültmek ya da tamamıla tasfiye etmekten dolayı kendisiyle gurur duyan teknolojik dünya, yavaş yavaş hem tabiatın hem de insan kültürünün yerini almıştır" (Mumford, 1996: 102). Omnicorp'un yöneticisinin Alex'in nasıl bu kadar iyi olduğunu sorması üzerine Dr. Norton "Yazılımı daha güçlü, donanımı daha güçlü... O artık daha iyi bir makine!" sözleriyle cevap verirken Alex Murphy'den mi yoksa herhangi bir kişisel bilgisayardan mı söz ediyor belli değildir.

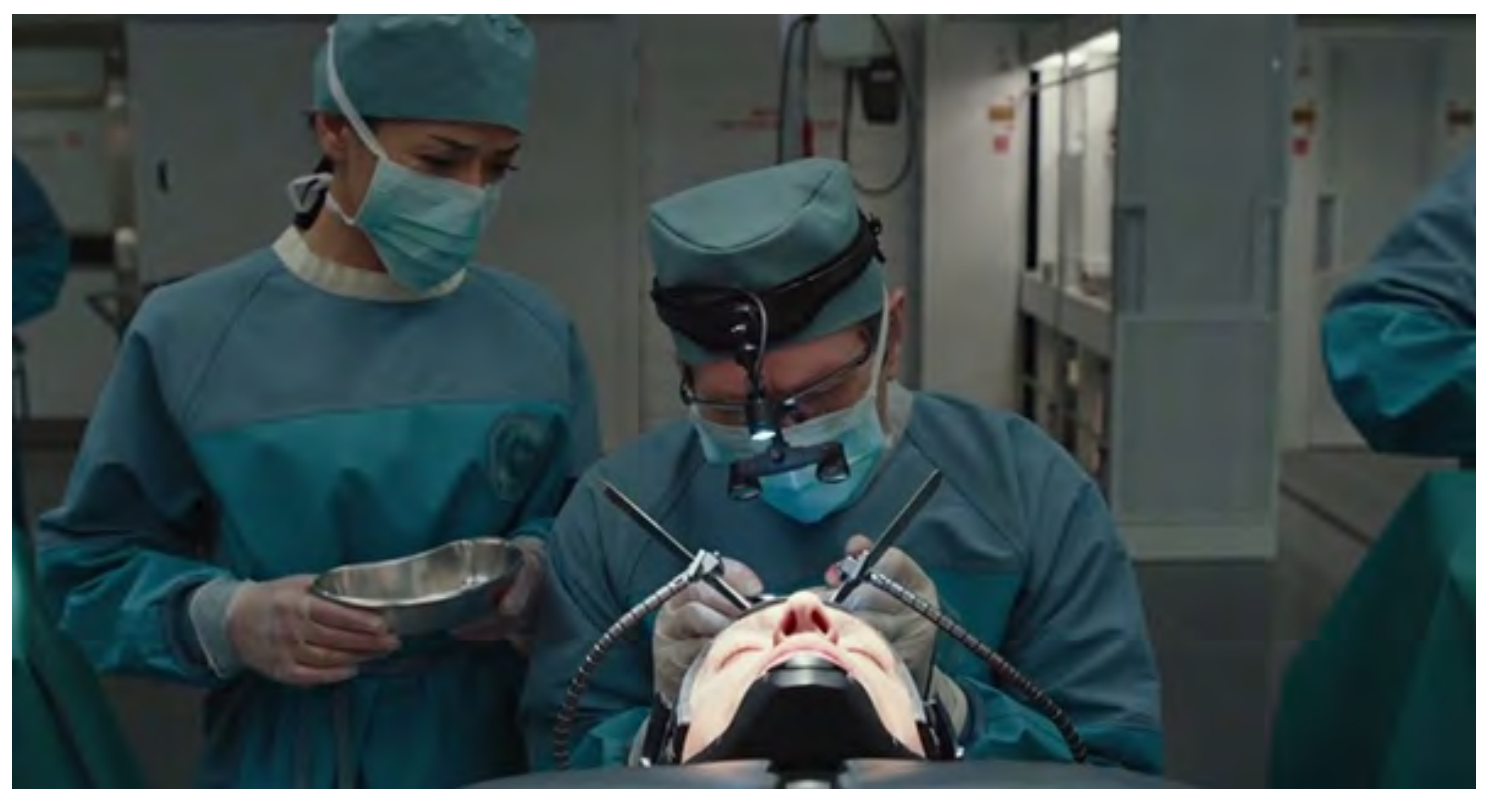

Görsel 3. Doktor, Alex'in Beynini “Kusursuzlaştırıyor”

İnsanın bir karar vermek zorunda kaldığı zaman tereddüt edeceğini, oysa RoboCop'un

16 Filmde Omnicorp'un da merkezinin bulunduğu ve gerçekte de Amerika Birleşik Devletleri' nin sanayi şehri olarak bilinen Detroit 18 Temmuz 2013 tarihinde iflasını açılamıştır. Dönemin belediye başkanı ve şehir meclisi üyeleri, 18.5 milyar Dolar olarak tahmin edilen borçları nedeniyle iflas başvurusunda bulunmuşken (www.usatoday.com), Sellar'ın "Omnicorp'un hayatta kalması buna bağlı." sözü, filmin gösterime girmesinden yalnızca bir yıl önce yaşanan finansal krize gönderme yapmaktadır. 
sisteminde her işi makinenin yaptığını ve Alex'in "sadece gelip geçici bir yolcu" olarak karar verme yükünden kurtarıldığını söyleyen Doktor'un son sözleri ilginçtir: “Alex şu anda kontrolün kendisinde olduğunu sanıyor. Ama kontrol onda değil. Bu özgür iradenin bir yanılsaması." Esasında teknikleştirme adını verdiğimiz şey tam olarak budur: Bireyin kendi yaptığı işlerde bulunmamasını sağlamak. Sellar ve Norton'un birlikteliğinde görünür kılındığ 1 şekliyle, ekonomik akılsallıkla araçsal aklın ortak temeli, düşünmeyi elden geldiğince biçimselleştirmek ve teknik usullere indirgemek suretiyle, onu kendi üzerine düşünümsel dönüş imkânından uzaklaştırmak ve yaşamın gerçekliğinden yalıtmaktır (Gorz, 2007: 158).

Sahnenin devamında, Omnicorp çalışanının "Kendini insan sanan bir makine yarattın." demesi üzerine Sellar'ın "Hayır, hayır... Kendini Alex Murphy sanan bir makine yarattık." sözü ise tüm robot anlatılarının temelinde bulunan fakat çoğu zaman gizli kalan paradoksu önümüze koymaktadır. Sellar' ın asıl söylemek istediği, insanın çoktan bir makine hâline gelmiş olmasına rağmen bunun farkında olmamasından ya da giderek gelişen yapay zekâsı yoluyla bir makinenin insanlaşmasından çok daha öte, daha derin bir şeydir. Çalışmamızın girişinde belirttiğimiz şekliyle, insanın uzunca bir süredir bir robota baktığında kendini, kendine baktığında ise bir robotu temaşa ettiği düşünncesi (Sussman, 2009: 39) Sellar'ın repliğinde açığa vurulur. "Makineler tasarlama yeteneğinin kendisi de sonuç olarak bir makine gibi tasarlanır; bir makine gibi işleme yeteneğine kavuşmuş tin, kendini, onun gibi işleme yeteneğindeki makinede tanır -gerçekte makinenin tin gibi işlemediğini, sadece bir makine gibi işlemeyi öğrenmiş tin olarak işlediğini fark etmez" (Gorz, 2007: 158).

\section{Bir Beyin, Bir El: Endüstriyel Kapitalizme Bunlar Yeter}

Görüldüğü üzere, filmin anlatısı kapitalizm eleştirisine de imkân tanıyacak bir genişlemeye sahne olmaktadır. Her şeyden önce, bir meta üretimi mantığında var edilen RoboCop, kalite kontrol testlerini geçtikten sonra, zırhının rengine varıncaya dek tüketici odak gruplarının düşünceleriyle şekillendirilmeye çalışılan bir ürün hâline gelir ${ }^{17}$. Hümanizmin kendi kendini şekillendiren insanının, endüstriyalizm ve kapitalizmle şekillenen insana dönüşmesi ironik olsa da son derece makuldür. Kapitalizm "özel sermaye mülkiyeti ile mülksüz ücretli emek arasındaki ilişki merkezinde yoğunlaşmış bir meta üretim sistemi" iken, endüstriyalizm "cansız maddi güç kaynaklarının mal üretiminde kullanılmasıdır" (Giddens, 2012: 53-54) ve her iki kavram üstü örtük biçimde üretimi yapan varlığın insansızlaşması (dehumanization) meselesinde uzlaşıp kaynaşarak felsefi bir genişlemeye kavuşmaktadırlar ${ }^{18}$.

17 Omnicorp'un çalışanlarından biri Sellar'a, odak gruplarının RoboCop'un zırh rengine dair isteklerini gösterir fakat Sellar hiç birini beğenmez ve RoboCop' un siyaha boyanması talimatını verir. Bu sahnede söylediği bir cümle filmin kapitalizmle bağlantısını kurmak açısından önemlidir, zira CEO "İnsanlar siz onlara verene kadar ne istediklerini bilmez." demektedir. Sellar'ın söyledikleri, Apple'ın kurucusu ve efsanevi CEO'su Steve Jobs'a (1955-2011) ait olduğu bilinen "Ürünleri odak gruplarına göre tasarlamak gerçekten zordur. Çoğu zaman insanlar, siz onlara gösterene kadar neye ihtiyaç duyduklarını bilmezler." (www.helpscout.net) sözüne aleni bir göndermedir.

18 Burada kendisine atıf yaparken önemli bir noktayı da belirtmek durumundayı: Modernliğin kuramsal boyutlarından ikisi olarak gördüğü endüstriyalizm ve kapitalizmin (diğer ikisi ise gözetim ve şiddet araçlarının kontrolüdür) birbirine indirgenmesine karşı olan Giddens, her ikisinin ayrı örgütsel kümelere işaret ettiğini vurgulamaktadır (2012: 56). Fakat pratikte kapitalizmin endüstriyalizmden ayrılması mümkün değildir. Kaldı ki, Giddens da endüstriyalizmin üretim biçiminden daha fazlası; bir toplumsal örgütlenme modeli olduğunu kabul etmektedir (2012: 54). Söz konusu örgütlenmenin büyük oranda üretim ve tüketim ilişkileri namına yapılandığını göz önünde bulundurduğumuz takdirde kapitalizm ve endüstriyalizmin anlamca olmasa bile işlevce özdeş olduğunu söylemek yanlış olmayacaktır. 
İnsan, endüstriyalizm-kapitalizm ikilisinin var ettiği sistem içinde yalnızca bir araçtır; değerini ise verimlilik belirlemektedir. Omnicorp'un CEO'su Sellar katıldığ1 bir televizyon programında, verimlilik söz konusu olduğunda bir sistemin insanlı ya da insansız olmasının umursanmayacağını ifade ederken kapitalizmin önceliğinin insan olmadığını da vurgulamış olmaktadir.

Diğer açıdansa, kapitalizmin ilk makinesinin, buharlı kazandan evvel, insanın bizzat kendisi, hatta ilk ürününün de yeni bir insan tipi olduğunu söylemek de mümkündür. Daha açık ifadeyle, kapitalizm, insanı bir ürüne, endüstriyalizm ise bir aygıta çevirmiştir. Performansın sabit tutulması sayesinde seri üretimin güvence altına alınması temel prensibine sahip mekanizm önce insanı standart ve tekdüze bir varlık haline getirir, bu yolla üretime katılan insan ve makine verimlilik ilkesinin teminatı olarak standartlaşmanın altında aynılaşır (Mumford, 2017: 259; Koyré, 2013: 135). Üstelik bu durum yalnızca fabrika sinırları içinde kalmaz; insan hayatının her alanına nüfuz eder. Kapitalist üretimin ihtiyaç duyduğu insan gücü, yalnızca fabrika sınırları içinde varlık kazanan bir işçi değil, içerde sattığı emeğini dışarda dolaylı biçimde de olsa geri alacak olan tüketicidir. Bu anlamda toptan üretim, toptan dağıtım ve toptan tüketim bireyin tamamına ihtiyaç duyduğundan "endüstriyel psikoloji çoktandır fabrika duvarları arasından çıkmıştır. İçe işlemenin çok yönlü gelişimi donmuş ve adeta mekanik tepkiler biçiminde kalıplaşmıştır" (Marcuse, 1968: 38).

Bu sebepledir ki RoboCop'un artık normal bir insan olarak hayatına devam etmesi mümkün değildir: Performans testlerini başarıyla geçmiş bir ürün olarak evine dönmüş ve suçlulara göz açtırmayan başarılı bir polis memuru olmuşsa da artık asla mesai bitiminde eve dönen normal bir aile babası olamayacaktır. RoboCop olmasının ardından ilk kez evine gitmeden önce "Eğer bir kalbim olsaydı gümbür gümbür atardı"19 diyen Alex, eşine sarıldığında onun tenini hissedemeyen, çocuğuyla zaman geçirmesi mümkün olmayan bir baba figürü olarak, üretim sistemine hizmet etmesi için bir fertten çok "türsel bir varlığa" dönüşmek zorunda kalan modern insanın temsilidir. İster soyut isterse de somut anlamıla anılsın, makine insanı canlı tuttuğu gibi onu güdük de bırakmaktadır (Adorno ve Horkheimer, 2010: 59, 61). Evine gitmesinin ardından Omnicorp binasına geri döndüğünde eski ortağ1 Jack Lewis'le (Michael K. Williams) karşılaşan RoboCop, hüzünle bundan böyle evinin laboratuvar olduğunu söyleyecektir. $\mathrm{O}$, artık, her işçi gibi, şirketin malıdır. Kendisi de Afro-Amerikan olan Dedektif Lewis'in “En azından artık doğru renktesin." şakası, RoboCop'un siyah bedeni ile kapitalizmin yüzyıllarca sürdürdüğü cebri kölelik arasındaki bağlantıyı muzipçe ortaya koyduğu kadar Memur Alex Murphy'in yeni varoluş biçimine de işaret etmektedir.

Alex'in ilk kez uyandırılmasının ardından yaşadığı şoka verdiği cevabı gösteren sahne de endüstriyalizm-kapitalizm okuması açısından anlam doludur. Omnicorp'un bir Amerikan şirketi olmasına rağmen RoboCop'un Çin'de üretilmesi bile başlı başına dikkat çekiciyken, Alex kapitalizmin egemenliğinde, seri üretim mamulü olmakla biricik kalmak arasında puslu bir sınırda duran çağdaş insandır. Tüm vücudu sökülüp-takılabilir, defalarca seri olarak üretebilir olduğundan seri üretim metaıdır; varoluş sancısı çeken bir varlık olaraksa biriciktir. Bu ikircikli hâl, yalnızca Alex'in değil, modern insanın kaderidir. Kapitalist yaşam pratiği içinde, "kurumların bakış açısıyla, kopyalanabilir seri üretim mallarına dönüşümüzün başarıyla tamamladığı, yedek'lerin (spare parts) daima kullanıma hazır hâlde beklediği yadsınamasa da tek tek kişiler açısından mesele hiç de öyle değildir" (Anders, 2018: 75). İnsan bir tür olarak ne denli soyutlamaya maruz kalırsa kalsın, birey modern düşüncenin 19 Oz Büyücüsü'nün Teneke Adam'nna bir gönderme daha. 
ya da kapitalizmin indirgemelerine her zaman direnmekte ve söz konusu direnç kendisini çoğu zaman varoluşsal bir kriz olarak göstermektedir. İnsan, her tür yapay ikame biçime bir başkaldırıyla cevap verirken (Baudrillard, 2012: 70) Dedektif Murphy'nin de yaşadığı bundan başka bir şey değildir.

Bir makine-insan olarak ilk kez uyanmasıyla birlikte yaşadığı şokun ardından laboratuvardan kaçmaya çalışan Alex Murphy'nin Omnicorp'un seri üretim bantlarının bulunduğu fabrika sahasına çıkması ve bu sahnenin Murphy'nin RoboCop'a dönüşmesinden sonra başına gelen ilk şey olarak gösterilmesi dikkatimizi çekmektedir. Laboratuvardan kaçmaya çalışan Alex, seri üretimde çalışan yüzlerce Omnicorp çalışanıyla karşılaşır. Hepsi bir örnek olan ve bir örnek malları üreten işçilerin RoboCop'la birlikte görülmesi, endüstriyalizmin soyut mamulü olan iş̧̧i ile somut mamulü olan makinenin görsel birlikteliğidir. Kaldı ki teorik anlamda işçilerle RoboCop'u ayırmak pek mümkün değildir; işçi üretime katılan bir aygitken bir aygit yeterince geliştirildiği takdirde pekâlâ bir işçidir. Bu açıdan, "otomasyon, insan bedeninin belli kısımlarının araç olarak kullanılmasıyla başlayan bir sürecin son aşamasıdır" (Mumford, 2017: 22).

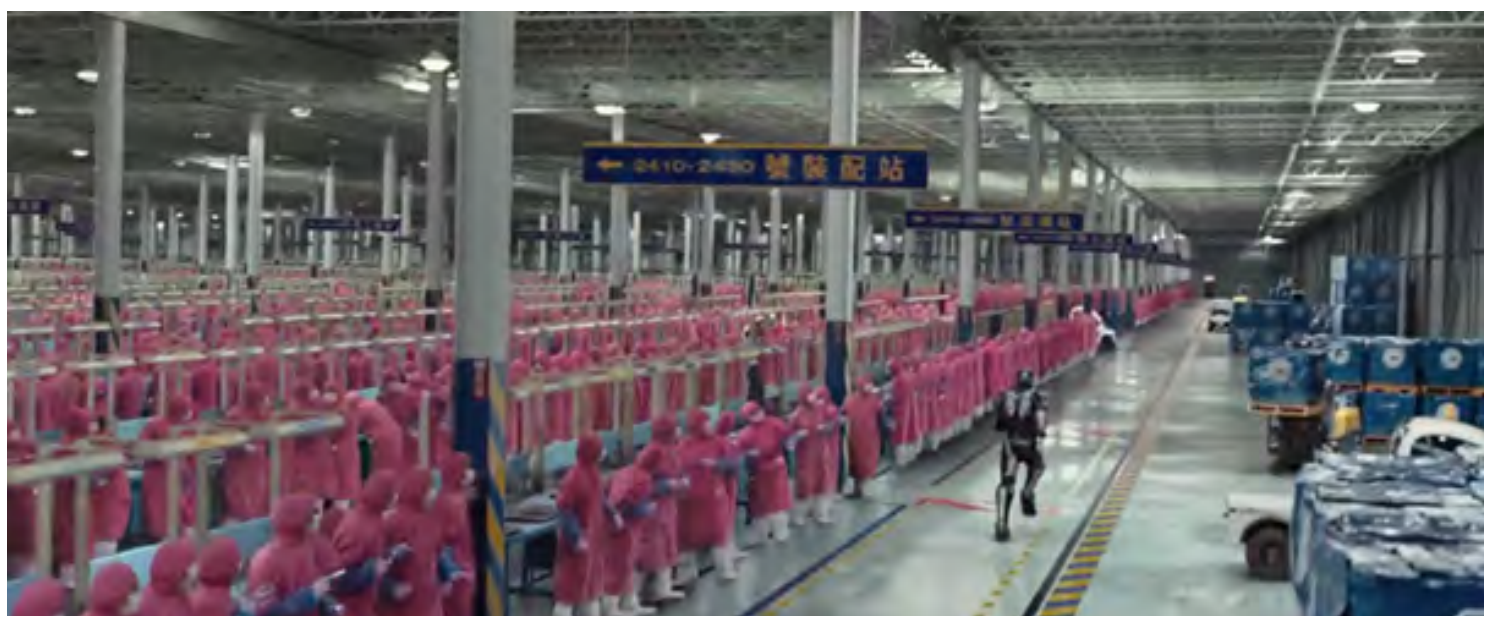

\section{Görsel 4. Seri Üretimin İlk ve Son Mamulü Bir Arada}

Demek ki, Kartezyen tasarımla çizilmeye başlayan daire Fordist üretim hattıla kapanmıştır $^{20}$, yahut Foucault'un belirttiği üzere modern makine-insanın varlığı, iki sicile birden işlenerek tamama ermiştir. İlk sicil, önce Descartes tarafından yazılan ve ardılı doktor ve filozofların devam ettirdikleri anatomik-metafiziksel izlek iken, ikincisi de beden üzerinde mutlak bir hâkimiyet kurmaya dönük işleyen tüm pratik usullerce meydana getirilen teknik sicildir (Foucault, 1992: 168-169). Açık biçimde görüldüğü gibi, filmde, Michel Foucalt'un (1926-1984) bahsettiği iki modern sicilin ilki Dr. Dennet Norton'da, ikincisi ise Omnicorp'un CEO'su Sellar'da şahsiyet kazanmaktadır.

Daha önce bahsettiğimiz gibi, eğer aygitların doğasında tek ve özel bir işi yapmak varsa, kapitalist üretim ağında işçinin insandan ziyade aygıt olduğu gerçeğini de kabul etmek durumundayızdır zira işçinin vücudu, biyolojik olarak bir eksiklik taşımasa bile

20 Fordizm, dar anlamiyla, Amerikalı girişimci Henry Ford'un (1863 -1947) ilk kez 1908 yılında ortaya koyduğu, bir taşıma bandı üzerinde çalışan her işçinin tek bir işlemde uzmanlaşmasıyla üretim yapılmasını temel alan yaklaşımıdır. Fakat günümüzde bu kavram, üretim-tüketim ilişkisinin kesintisiz şekilde sürmesini sağlayacak bir yaşam ve insan tipinin yaratılmasını ifade edecek biçimde genişlemiştir (Harvey, 2012: 18). 
işlevsel olarak daralmaya uğratılmıştır. Endüstriyel kapitalizmde insanın her uzvu sağlam olsa bile birçoğunu kullanmasına gerek yoktur çünkü yapmak zorunda olduğu tek ve özel bir iş, genelde, yine tek ve o iş için özelleşmiş bir uzvunun çalışmasını öngörür ${ }^{21}$. Hatta diğer parçalarının işe karışması çoğu kez verimliliğe negatif etki eden, istenmeyen bir durumdur (Ritzer, 2014: 60-61). Endüstriyalizmin çıktısı bir fetiş olmak dışında her türlü vasfını yitiren metaların sonsuz havuzunda ortada kalan insan "ondan nesnel olarak beklenen alışılmış tepki ve işlevlerin kesişme noktasına dek küçülür" (Adorno ve Horkheimer, 2010: 49). Bir beyin ve bir el makineyi işletmeye yetecekse eğer, insan bu ikisi kalana değin küçültülmek durumundadır; serinin 4. filminde Alex Murphy'nin başına gelen budur.

Belirlenmiş bir işi yapmak konusundaki determinizm çağdaş insanın özgürlüğünün de ortadan kaldırılması demektir. Burada belirli bir işi yapmak konusunun üretimle sınırlı kalmadığı, tüketimi de içine alacak şekilde genişlediği söylenebilir. Seri üretim, nihayetinde, tüketime muhtaç olduğundan "sürü insanının üretilmenin yolu, insanlara seri üretim mallarını tükettirmekten geçer" ve böylece bir döngüye ulaşılır çünkü "bu aynı zamanda, seri üretim mallarının tüketicisinin, tüketimiyle, sürü insanının üretim kadrosunda yer alması demektir" (Anders, 201: 127). Fakat sosyolog Zygmunt Bauman'a (1925-2017) göre Fordizm'deki esas can alıcı mesele sermayenin çeşitli teknikler kullanarak emeği kendisine devamlı olarak bağlamasıdır ve "muazzam fabrika duvarları her iki tarafı da ortak bir hapishaneye kapatmıştır" (Bauman, 2011:33). Filmde RoboCop'un Omnicorp'un Çin' deki üretim tesisinden firar teşebbüsü, bireyin Fordist hapishaneden kurtulma çabasıdır ama kaçabileceği bir yer yoktur zira Bauman'ın bahsettiği hapishanenin mekâna bağlı olmayan soyut bir ilişkiler ağına işaret ettiğini görmek çok zor değildir.

“Otomatikleştirme sürecinde insan bilinci akıldışı bir şekilde yansıtılırken; bu şizoid özelliklere sahip işlevsel dünyada artık yalnızca saplantılarla karşılaşılmaktadır" diyen Baudrillard, Dedektif Murphy'nin saplantılı kaçma isteğini bizim için çözümlemiş olur. Üstelik bununla da kalmaz, "[b]urada yalnızca nesneye yönelik patafizik ya da uydurma teknik çözümler biliminden söz edilebilir" (2014: 142) de diyerek Dr. Norton'un çözümünü de açımlar. Alex şok geçirdiği zaman Doktor, laboratuvar çalışanlarından onu kapatmasını değil, aksine rahat bırakmasını ister, RoboCop'un ihtiyacı olan şey biraz olsun delirme özgürlüğüdür. Binlerce işçinin arasından koşarak bahçeye çıktığında, Bauman'ın hapishane metaforunu destekler biçimde, fabrikanın devasa savaş robotları ED-209'lar tarafından korunduğu görülmektedir. RoboCop duvarların dışına atlayıp endüstriyalizmin hiç uğramadığı bir kırsal alanda çeltik tarlalarına sakince pirinç eken Çinli köylülerle karşılaşınca işler değişir; Dennet Norton asistanına Alex'i kapatması için talimat verir ve sistemine merkezden müdahale edilen RoboCop tarlanın ortasında toprağa düşer. Bu sahneden anlarız ki bizim için endüstriyalizmin hüküm sürmediği bir dünya yoktur. Daha doğrusu, öyle bir dünya mevcutsa bile artık bizim orada var olma şansımız yoktur.

Dr. Norton'un Alex'in krizine bir teknik çözümü daha bulunmaktadır. Uzun bir günün ardından, RoboCop'un sistemi temizlenip kanı değiştirilirken Doktor, laboratuvar teknisyenlerinden Alex'e sakinleştirici de vermelerini şu sözlerle ister: “Biraz antidepresan

21 Gerçekten de Henry Ford, fabrikasının üretim hattında 7882 işlem varken bunlardan sadece $\% 12$ 'sinin tamamen sağlam adamlar tarafından yapılması gerektiğini; 670 tanesinin bacakları olmayanlar, 2637'sinin tek bacaklı olanlar, 715'inin tek kollular, 10'unun ise körler tarafından da yapılabildiğini gururla söylerken (Aktaran Buck-Morrs, 2000: 103) dolaylı olarak bir iş̧̧inin yaşayacağı soyut ampütasyonu da arz etmektedir. 
verin, güzel rüyalar görsün." Modern insanın parçalanmış bilincinin gerçekle baş edecek hâli kalmazsa devreye uyuşturucular girmektedir. Uzun zamandır, olmak istemediğimiz benliklerden ya da zorlanarak yaptığımız rutinlerden kaçışımız antidepresanlar vasıtasıyla gördüğümüz tatlı düşler eliyle olmaktadır (Touraine, 2002: 234). Eğer makine-insanın gerçeklerden tümüyle kaçabilmek gibi bir imkânı yoksa Kartezyen saflaştırma yoluyla bedenden sıyrılabilme illüzyonu yeniden işe koşulmaktadır. İnsan, kâbus gibi gerçeklere mahkûm edilmişse de, kendisi gibi seri üretim metaı olan ilaçları kullanarak güzel rüyalar görme özgürlüğüne sahiptir.

\section{Sonuç}

Şimdi, “Alex Murphy nasıl RoboCop olur?" sorusuna eleştirel teorinin “ölmeden olamaz" cevabını vereceğini söyleyebiliriz. Karamsar eleştirmenler için Murphy'nin ölümü, düşmanlarının koyduğu bombadan çok, onun bir makine olarak yeniden doğuşuna imkân verecek soyut ve somut indirgemelerin katılımıyla gerçekleşmekte; "kendi lanetli yanını temizlemeye çalışan her şeyin başına geldiği gibi" (Baudrillard, 2012: 102) insan da kusurlarından arındırılmaya çalışılırken ölüm fermanı imzalanmaktadır. Bu açıdan, Memur Murphy'nin RoboCop'a dönüşmesi ancak hümanizm-mekanizm-endüstriyalizm-kapitalizm çatısının altında mümkündür. Burada bizler için asıl ürpertici olan, anlatılanın Alex Murphy kadar bizim de hikâyemiz olduğudur - de te fabula narratur ${ }^{22}$. Siborg Manifesto'nun yazarı Donna Harraway da "yirminci yüzyılın sonlarına, bizim mitik zamanımıza gelindiğinde, hepimiz kuramsallaştırılmış ve imal edilmiş makine-organizma melezleriyiz; kısaca siborguz" (2006: 4) demekle RoboCop'a döndürülen Alex Murphy ile aynı hikâyeyi paylaştığımızı vurgulamaktadır yalnızca.

Ortak hikâyemizin başlangıcını ise modern Kartezyen tasarımın dünyayı düşünsel anlamda şekillendirmeye durduğu 17. Yüzyılın ilk yarısına tarihlemek mümkündür. Ruh ve madde ayrımına giden mekanikçi dünya tasarımı, zihne ayrıcalıklı bir konum atfetmekle hümanizmi tahkim ediyor gibi görünse de robotlaşmamızın ilk adımıdır. Zihin ve dünyanın karşılıklı eşitlik üzerine kurulu olduğu varsayılan bir ikiliğe indirgenmesi, hem dünyanın hem de zihnin rasyonel prensiplere göre işleyen süreçler olarak algılanmasına sebep olmuştur. Rasyonalizasyon öngörülebilirliği, verimliliği ve otomatikleşmeyi doğal biçimde koşulladığından, bunların tümünü yerine getirebilen makinenin yükselişi de kaçınılmaz hâle gelmiştir. Bu açıdan, Lewis Mumfod'un dediği gibi, makinenin yükselişi ve insanın düşüşü aynı sürecin iki parçası olarak anlaşılmalıdır (2015: 520).

İlaveten, 18.yüzyılın ikinci yarısından itibaren makinenin kapitalizme hızlı biçimde eklemlenerek endüstriyalizmi doğurması insan için ikinci bir daralma demektir. Üretimde standardın makine tarafından belirlendiği bir dünyada insan, aygıt kullanan bir varlık olmanın ötesine geçerek makinelerin kullandığı bir aygıta dönüşmek; her zaman tekniğin elinin altında durmak zorundadır. Üstelik gündelik hayatımızın tamamı makine temposu ve standartlarına göre belirlendiği ve küreselleşme sayesinde makine determinizmi her yere yayıldığ 1 için, söz konusu daralma yalnızca makinenin arkasında üretime katılan işçilerin değil bütün insanların problemidir. Kapitalist sistemin tüm örgütlenmeleri kendi gerekleri uyarınca dönüştürebilme ve standartlaştırabilme başarısı, insanın tüm dünya ölçeğinde benzer sosyal organizasyonların

22 Tüm eleştirel teoriyi etkilemiş olan Karl Marx'ın (1818-1883) Kapital'inin [1867] önsözünde geçen Latince deyiş. Tam hali “Quid rides? De te fabula narratur" olan söz "Neden gülüyorsun? Senin hikâyen anlatıliyor" anlamina gelmektedir. 
içinde varlığını sürdürmek durumunda kalan soyut bir varlığa dönüşmesinin yolunu açıyorsa, bu, artık insanın da seri üretim ürünü bir meta olduğunun resmidir.

$\mathrm{Bu}$ noktada, yabancılaşma yoluyla makineye karşı durmaktan bahsetmek de anlamsızdır. Tıpkı Alex Murphy'nin zihninin tamamen dijitalleşmesine rağmen kendisinin bunun farkında bile olmaması gibi, çağdaş insan köleliğine rağmen kendisini özgür hissedebilir. Fakat gerçek bir kriz anında özgürlüğünün sandığı kadar engin olmadığını anlayacaktır. Son sahnede Sellar'ın kendisini tutuklamak isteyen RoboCop'a "Bunu yapamazsın, bunun için programlanmadın. Beraber çalışmalıyız, seni hayatta tutacak teknolojiye bir tek ben sahibim çünkü." demesi insanın kapitalizmin izin verdiği ölçüde varoluşa sahip olduğunu ima etmektedir.

Sellar'ın "Kabul edelim, sen bir robotsun." sözünden sonra, Alex içinde kalan son insanlığa sarılıp yazılımına karşı gelerek Sellar'a karşı tetik çekmeyi başarsa bile değişen pek bir şey yoktur. RoboCop'un eski hâline dönmesi mümkün olmadığından artık yaşamını bir insan-makine olarak sürdürecektir -tıpkı hepimiz gibi. Üstelik filmin, televizyon yapımcısı Pat Novak (Samuel L. Jackson) tarafından bağırarak sarf edilen "Makineleri insan hakları ihlali olarak görenlere şunu demek istiyorum: Mızmızlanmayı bırakın!" sözüyle bitmesi, büyük bir olasılıkla, yazgımızın kaçınılmazlığını da yüzümüze vurmaktadır.

\section{Kaynakça}

Adorno, Theodore ve Horkheimer, Max. (2010). Aydınlanmanın Diyalektiği: Felsefi Fragmanlar. Çevirenler: Nihat Ülner ve Elif Öztarhan Karadoğan. İstanbul: Kabalcı Yayınları.

Asimov, Isaac. (1950). I, Robot. New York: Genome Press.

Anders, Günther. (2018). İnsanın Eskimişliği I. Cilt. Çevirenler: Herdem Belen ve Hüseyin Öztürk. İstanbul: İthaki Yayınları.

Batukan, Can. (2017). Robo-tizm. İstanbul: Altı Kırkbeş Yayınları.

Baudrillard, Jean. (2012). Kötülüğ̈̈n Şeffaflı̆ğ: Aşırı Fenomenler Üzerine Bir İnceleme (5.Baskı). Çeviren: Işık Ergüden. İstanbul: Ayrıntı Yayınları.

Baudrillard, Jean. (2014). Nesneler Sistemi (3. Baskı). Çeviren: Oğuz Adanır ve Aslı Karamollaoğlu. İstanbul: Boğaziçi Üniversitesi Yayınları.

Bauman, Zygmunt. (2011). Bireyselleşmiş Toplum (2. Bask1). Çeviren: Yavuz Alogan. İstanbul: Ayrıntı Yayınları.

Buck-Morrs, Susan. (2000). Dreamworld and Catastrophe: The Passing of Mass Utopia in East and West. Cambridge \& London: MIT Press.

Crary, Jonathan. (2015). 7/24: Geç Kapitalizm ve Uykuları Sonu. Çeviren: Nedim Çatlı. İstanbul: Metis Yayınları.

Descartes, René. (2010/1644). Felsefenin İlkeleri (12. Bask1). Çeviren: Mesut Akın. İstanbul: Say Yayınları.

Descartes, René. (2013/1641). Metafizik Üzerine Düşünceler. Çeviren: Çiğdem Dürüşken. İstanbul: Kabalcı Yayınları. 
Foucault, Michel. (1992). Hapishanenin Doğuşu. Çeviren: Mehmet Ali Kılıçbay. İstanbul: İmge Yayınları.

Freyer, Hans. (2014). Sanayi Çă̆̆. Çevirenler: Bedia Akarsu ve Hüseyin Batuhan. İstanbul: Doğu Batı Yayınları.

Giddens, Anthony. (2012). Modernliğin Sonuçları (5. Baskı). Çeviren: Ersin Kuşdil. İstanbul: Ayrıntı Yayınları.

Gorz, André. (2008). İktisadi Aklın Eleştirisi: Çalışmanın Dönüşümleri/Anlam Arayışı (2. Baskı). Çeviren: Işık Ergüden. İstanbul: Ayrıntı Yayınları.

Harraway, J., Donna. (2006). Siborg Manifestosu: Geç Yirminci Yüzyılda Bilim, Teknoloji ve Sosyalist-Feminizm. Çeviren: Osman Akınbay. İstanbul: Agora Kitaplı̆̆ı.

Harraway, J., Donna. (2010). Başka Yer. Çeviren: Güçsal Pusar. İstanbul: Metis Yayınları.

Harvey, David. (2012). Postmodernliğin Durumu (6. Baskı). Çeviren: Sungur Savran, İstanbul: Metis Yayınları.

Kacznsky, J., Theodore. (2013). Sanayi Toplumu ve Geleceği (2. Baskı). Çeviren: Kolektif Çalışma. İstanbul: Kaos Yayınları.

Kakoudaki, Despina. (2017). Robot Anatomisi. Çeviren: Deniz Aras. İstanbul: Kolektif Kitap.

Koyré, Alexandre. (2013). "Filozoflar ve Makine". Koyrénin Bilimsel Düşünce Tarihi Üzerine Denemeleri (Derleyen: Talip Kabadayı). İstanbul: Bilgesu Yayınları.

Küçükalp, Kasım ve Cevizci, Ahmet. (2017). Batı Düşüncesi: Felsefi Temeller (4. Baskı). İstanbul: İsam Yayınları.

Marcuse, Herbert. (1968). Tek Boyutlu İnsan: İlerin Endüstriyel Toplumun İdeolojisi Üzerine Bir İnceleme. Çeviren: Seçkin Çağan. İstanbul: May Yayınları.

Mollaer, Firat. (2016). Modernlik Kehanetleri. Ankara: Orion Yayınları.

Mumford, Lewis. (1996). Makine Efsanesi. Çeviren: Fırat Oruç. İstanbul: İnsan Yayınları.

Mumford, Lewis. (2015). İnsanın Durumu. Çeviren: Yusuf Kaplan. İstanbul: Açılım Kitap. Kitap.

Mumford, Lewis. (2017). Teknik ve Uygarlık. Çeviren: Emre Can Ercan. İstanbul: Açllım

Postman, Neil. (2006). Teknopoli: Yeni Dünya Düzeni (2. Bask1). Çeviren: Mustafa Emre Y1lmaz. İstanbul: Paradigma Yayınları.

Ritzer, George. (2014). Toplumun McDonaldlaştırılması: Çağdaş Toplum Yaşamının Değisşen Karakteri Üzerine Bir Inceleme (3. Baskı). Çeviren: Şen Süer Kaya. İstanbul: Ayrıntı Yayınları.

Sawday, Jonathan. (2007). Engines of the Imagination: Renaissance Culture and the Rise of the Machine. London \& New York: Routledge.

Smelik, Anneke. (2010). “Cinematic Fantasies of Becoming-Cyborg”. The Scientific Imaginary in Visual Culture (ed. Anneke Smelik). Goettingen: V\&R unipress. 
Sweedler, Milo. (201). "Class Warfare in the RoboCop Films" Jump Cut: A Review of Contemporary Media, No. 56, Winter 2014-2015. http:/ / www.ejumpcut.org/archive/jc56.20142015/SweedlerRobocop/text.html, Son Erişim Tarihi: 15.11.2018.

Sussman, Herbert. (2009). Victorian Technology: Invention, Innovation, and the Rise of the Machine. Oxford: ABC Clio.

Touraine, Alan. (2002). Modernliğin Eleştirisi (4. Baskı). Çeviren: Hülya Tufan. İstanbul: Yapı Kredi Yayınları.

Wallerstein, Immanuel. (2012). Tarihsel Kapitalizm ve Kapitalist Uygarlı (6. Bask1). Çeviren: Necmiye Alpay. İstanbul: Metis Yayınları.

Westfall, Richard. (2008). Modern Bilimin Oluşumu (16. Baskı). Çeviren: İsmail Hakkı Duru. Ankara: Tübitak Yayınları.

------, "Detroit becomes largest U.S. city to enter bankruptcy", https:/ / www.usatoday. com/story/news/nation/2013/12/03/detroit-bankruptcy-eligibility/3849833/, Son Erişim Tarihi: 01.11.2018.

------, "Why Steve Jobs didn't listen to his customers", https:/ / www.helpscout.net/ blog/why-steve-jobs-never-listened-to-his-customers/, Son Erişim Tarihi: 03.11.2018. 